\title{
Community-based tourism and its potential to improve living conditions among the Hananwa of Blouberg (Limpopo Province), with particular reference to catering services during winter
}

\author{
C C Boonzaaier and Loudine Philip
}

\begin{abstract}
Opsomming
Die Hananwa is ' $n$ relatief selfversorgende gemeenskap van Tswana-Hurutshe herkoms wat in relatiewe afsondering bo-op Blouberg in die Limpopoprovinsie woonagtig is. As gevolg van hulle af-gesonderdheid is die gemeenskap steeds baie tradisioneel georïenteerd wat hulle kulturele aktiwiteite betref.

Die doel van hierdie studie was om ondersoek in te stel na die moontlikheid dat die gemeenskap voedsel kan voorsien aan ' $n$ stat (motse) vir besoekers wat bo-op die berg vir toeristeverblyf opgerig is. Sodanige voorsiening van voedsel aan die be-soekerstat sou in lyn wees met die doelwitte van gemeenskapsgebaseerde toerismeontwikkeling waarvolgens entrepreneurskap deur die ontwikkeling van kennis en vaardighede gevestig word sodat die plaaslike bevolking op direkte en indirekte wyse voordeel uit die besoekerstat kan trek. In hierdie ondersoek is die gemeenskap se gesindheid ten opsigte van toerisme en die rol wat logistiese dienste soos die voorsiening en voorbereiding van voedsel sou kon speel om van die projek 'n sukses te maak, ook bepaal. Aandag is gegee aan beleid ten opsigte van die beskerming van die Hananwa se kulturele erfenis - in besonder hulle dieetpatroon - teen die verwagte impak van toerisme.
\end{abstract}

Al elf huishoudings in die stamwyk waarin die besoekerstat geleë is, is besoek, en twee huishoudings in die aangrensende stamwyk is as 'n steekproef vir kontroledoeleindes besoek. 'n Kwalitatiewe navorsingstrategie is gevolg en data-insamelingstegnieke soos individuele onderhoude en deelnemende waarneming is gebruik. In die proses is daar deurentyd gepoog om gemeenskapsbetrokkenheid te bewerkstellig deur die inwoners se oordeel oor ver-bandhoudende sake soos toerisme en die volhoubaarheid daarvan, voedselresepte en die voorbereiding daarvan vir toeriste te bepaal en voorstelle van die inwoners te kry met besondere verwysing na die voorsiening van voedsel in die winter.

Hierdie artikel gee dus 'n aanduiding van die Hananwa se gesindheid jeens toerisme, die voedselsoorte wat deur individuele huishoudings verbou word, bepaalde resepte en die wyse waarop die mees algemene en belangrikste voedselsoorte voorberei word, veral in die winter. Terselfdertyd word moontlike aanpassings aan die tradisionele dieet voorgestel om dit by Westerse smaakvoorkeure te laat aanpas, en aanbevelings ten opsigte van bepaalde dienste word ook gemaak ten einde soveel huishoudings moontlik te laat voordeel trek uit die besoekerstat.

\section{- Prof C C Boonzaaier}

Department of Anthropology \& Archaeology University of Pretoria

\section{- Ms L Philip}

Department of Anthropology \& Archaeology University of Pretoria

\section{BACKGROUND}

The Blouberg (originally spelled Blaauwberg) is the most western extension of the Soutpansberg in the Limpopo Province. A gap of approximately 30 kilometres separates the Soutpansberg range proper from Blouberg. Blouberg's coordinates are S23 $05^{\prime}$ and E2900'. The surrounding plains are inhabited by a large population, but the mountain itself is sparsely populated by the descendants of the subjects of the traditional leader Kgoši Lebôhô to the west and of those of Kgoši Kibi to the east.

The mountain and its environs has been occupied by the Hananwa under the hereditary leadership of the Lebôhô lineage since at least the 1820s, when the Hananwa arrived as a group of refugees that had splintered off from the Hurutshe of Botswana. They displaced the Madebana, who inhabited the area at the time. After their arrival, the Hananwa split into two groups, one under Lebôhô and the other under Kibi. Kibi and his people moved away and settled in the eastern parts of the Blouberg (Breutz 1953:20; Krige 1937; Lestrade 1928; Roberts 1916; Van Schalkwyk 1995:68-75).

One of the most important and tragic events in the Hananwa's history after they settled at Blouberg was the siege of traditional leader Kgoši Kgalushi (Ratshaatshaa) Lebôhô's stronghold on top of the mountain in 1894 by General Piet Joubert of the Zuid- 
Afrikaansche Republiek (ZAR) (Sonntag n.d.:XV). From the beginning of May until the end of July 1894, the forces under the command of General Joubert besieged the Hananwa in an effort to subjugate them. Eventually, on 31 July 1894, Kgoši Lebôhô surrendered to General Joubert. Kgoši Lebôhô and his councillors were taken to Pretoria. Although a military court found Kgoši Lebôhô guilty of not paying taxes to the government and of not observing the laws of the land, he was never sentenced. Kgoši Lebôhô remained in prison for six years. When the British occupied Pretoria in 1900, he was immediately set free. He returned to Blouberg to rule over his people until his death in 1939. After the Hananwa-Boer war, the Hananwa women and children had to work for farmers for a period of five years without any compensation, other than food and clothing. However, most of them found their way back to Blouberg (Joubert \& Van Schalkwyk 1999; Sonntag n.d.:118,119,127,128,147,148; Van Schalkwyk \& Moifatswane 1991).

The only access to the top of the mountain is footpaths winding their way up several kilometres through thick forest from the foot of the mountain. Due to this isolated setting, the community on top of the mountain is still very traditional in its cultural practices. Homesteads (metse, sing. motse), are spread out along the top of the mountain, and the structures are examples of the traditional Hananwa hut type. The homesteads are largely self-sufficient, as the people cultivate their own food and tend their own livestock. They also gather edible plants from their natural environment. Those who can afford to do so buy items such as soap, personal toiletries, oil and the odd packet of sugar from the spaza shop at the bottom of the mountain.

Most members of the community living on top of the mountain are children under the age of twelve and adults over the age of forty-five (with women outnumbering men five to one). Most of these households have some external income, either from an old-age pension, a disability pension or a government child support grant paid to one or more members of the household. There are virtually no local job prospects. This has meant that these people have had to become self-sufficient for their daily dietary needs. Whatever they do not grow, they collect from nature, especially during summer, when there is an abundant variety of edible foodstuffs available in their environment, and to a lesser extent in winter.

In 2003, the provincial government erected a visitor homestead (motse) on Blouberg on the farm The Grange, which is owned by the Hananwa, for use as tourist accommodation. The design of the visitor motse was based on the ideal principles of how a motse should be laid out according to the Hananwa who live on top of the mountain. The visitor motse is linked to another visitor motse at the bottom of the mountain. Both form part of the so-called African Ivory Route concept, an initiative by the Limpopo Province Directorate Tourism which aims to empower and benefit disadvantaged rural communities in the province through tourism. Unlike the bottom visitor motse, which is managed by the Directorate Tourism, the top visitor motse was established with the aim of empowering the community on top of the mountain to manage the visitor motse by themselves. Hence, the objectives in respect of the top visitor motse satisfy the objectives of the African Ivory Route even better than the bottom visitor motse, in that it is meant to empower local people to take responsibility for tourism in their own communities and to promote communitybased tourism by developing the necessary knowledge and skills to run the visitor motse (Directorate Tourism 2002).

In order to narrow the research area to a more manageable proportion, it was decided to concentrate mainly on The Grange, on the eastern side of the mountain. There are only 11 metse on The Grange, but it was assumed that they display the same living conditions as those found on the western side of the mountain (generally referred to as Malebôhô by the residents), which consists of 52 metse. The latter area is separated from The Grange by an uninhabited stretch of land, approximately four kilometres long (a rocky outcrop separates the eastern side of the mountain from the western side). Due to the fact that both The Grange and the Malebôhô area are inhabited by the Hananwa community and that the topography and climatic conditions are the same, the chances that conditions at The Grange would be representative of those of the whole community were extremely high. Nevertheless, in order to test and verify the truth of this assumption, two households were randomly chosen and interviewed on the western (Malebôhô) side of the mountain.

The main objective of this study was to determine whether this community could be empowered to benefit financially from the visitor motse on top of the mountain; and if so, how. The visitor motse itself belongs to the community and if it is properly managed, it could provide income in an area where job prospects are virtually non-existent. Since its completion at the end of 2003, the visitor motse has been largely underutilized in terms of its potential advantages for the Hananwa and the cultural experience staying there could offer tourists. (It must be emphasised that the study was conducted only seven months after the completion of the visitor motse and that only three bookings had been received until the time when the study was undertaken.) Hence, it was decided to do a feasibility study focusing on the possible role that local food could play in making this incentive work better, even in winter, when the supply of crop plants is limited. Since the visitor motse is situated on the eastern periphery of The Grange, it is logistically more viable for the people in this area to provide the visitor motse with supplies such as food and services, such as the preparation of the food, but this should not exclude any possible contributions by households from the western side. Four factors were considered::

- the community's attitude towards tourism in general and the people's expectations with regard to the project in particular;

- the conservation and presentation of Hananwa cultural heritage with particular reference to their 
dietary pattern;

- the availability and variety of crop plants during winter and the way the Hananwa normally prepare these foods;

- the role ordinary logistical services such as the provision and preparation of food can play in making this project successful.

At first glance, it might seem that only a few individuals would benefit from providing services in the form of cleaning, cooking, providing food supplies, etc. to the visitor motse. However, in addition, visitors will also be guided along a cultural route that has already been developed. As they visit various metse on the cultural route on The Grange and in the Malebôhô area, visitors will have an opportunity to observe and even participate in authentic cultural practices and activities. This will in turn generate money for the community, as a fixed tariff has been determined for each motse that is visited. This means that these places of attraction (the local metse) and the people who live there will form part of all three levels of the total product, based on the model developed by Swarbrooke (1995:45; see Figure 1). The core product consists of those attributes that really attract tourists. According to Swarbrooke (1995:44), the core products are often intangible and highly subjective, such as atmosphere, experience, relaxation or convenience. They are sought after by tourists as a solution for their problems or needs (cf. Wang 1999). Access to the product implies that the community, in collaboration with marketers, have to turn the core product into a tangible product, an entity which customers can purchase to satisfy their needs. This tangible product can have different characteristics, such as a brand name, quality (of services), safety, a range of attractions and packaging. Finally, there is the augmented product which is aimed at ensuring the comfort and satisfaction of the tourist via the provision of additional services. Although the weather is a factor that can affect the core product, provision should be made to minimize its effect as far as possible (Swarbrooke 1995:45). If the Blouberg project is run in a responsible way, bearing in mind the principles outlined by Swarbrooke (1995), it will contribute to promoting tourism in this area as a whole.

\section{RESEARCH DESIGN}

The study to determine the crop plants cultivated during winter by the Hananwa on Blouberg was conducted from 28 June to 11 July 2004. (Winter was chosen, as it was assumed that what was possible in winter was the minimum potential supply, and that in summer this offering can be larger and more varied.) A basic qualitative research strategy was followed, employing qualitative research techniques in this explorative, descriptive and explanatory study to reach the set research objectives. Selected techniques from the Participatory Action Research (PAR) model were used, as these techniques (discussed in more detail below) proved to be appropriate to achieve the research objectives formulated above. Not only do they complement and reinforce each other, but they also aid in triangulation. Each technique enabled the re- searchers to obtain different perspectives on the topic, as suggested by Babbie and Mouton (2001:275), Pelto and Pelto (1993:77-81) and Strauss and Corbin (1998:11).

\section{Gaining access}

Access to the community was gained via the local Blouberg Community Tourism Association, which consists of members of the Hananwa community, as well as the royal family of Lebôhô. The guides and interpreters came from the area and they were knowledgeable regarding the language, customs and practices of the Hananwa. This was important, because following the correct etiquette when being introduced to the participants proved invaluable in establishing a trust relationship from the outset.

\section{Selection of informants}

The areas on top of Blouberg that are occupied consist of two wards separated by a rocky outcrop. The Grange is situated on the eastern side of the mountain and the Malebôhô area on the western side. The visitor motse is situated on The Grange, so the study focused on this area. All 11 homesteads in this area were visited and interviewed. Since these two wards share the same topography, climate and culture, the results were verified by visiting only two homesteads on the western (Malebôhô) side. These two homesteads were selected randomly.

Since the study focused on the topic of food, the person usually responsible for cooking and related chores in every household was the person selected for each interview. This task usually falls on the youngest or most junior female member of the family. However, the older women were very interested in the questions that were asked, and all offered answers, most of which confirmed the responses of the interviewees. Hence, the actual interviews can best be described as focus group discussions.

\section{Participant Action Research (PAR)}

To enhance the holistic and contextual approach used in this study, selected techniques of the PAR approach were followed during the data gathering process. This approach focuses on the involvement and participation of all role-players in a particular research project in order to achieve solutions for problems or jointly set objectives. Hence, this approach relies heavily on the local knowledge as well as the perspectives of the participants (informants) regarding their own situation and environment. Because local knowledge and perspectives are experience-based, they represent unique knowledge and insight into the participants' culture and problems. As a joint endeavour between the researcher and the community, the study can best be described as the collective generation of knowledge rather than the mere collection of data. The research results in action, with the ultimate goal of improving the quality of life of the communities concerned (Coetzee et al. 2001:545; Strydom 2005 (b):408-412). A variety of data-generation techniques 


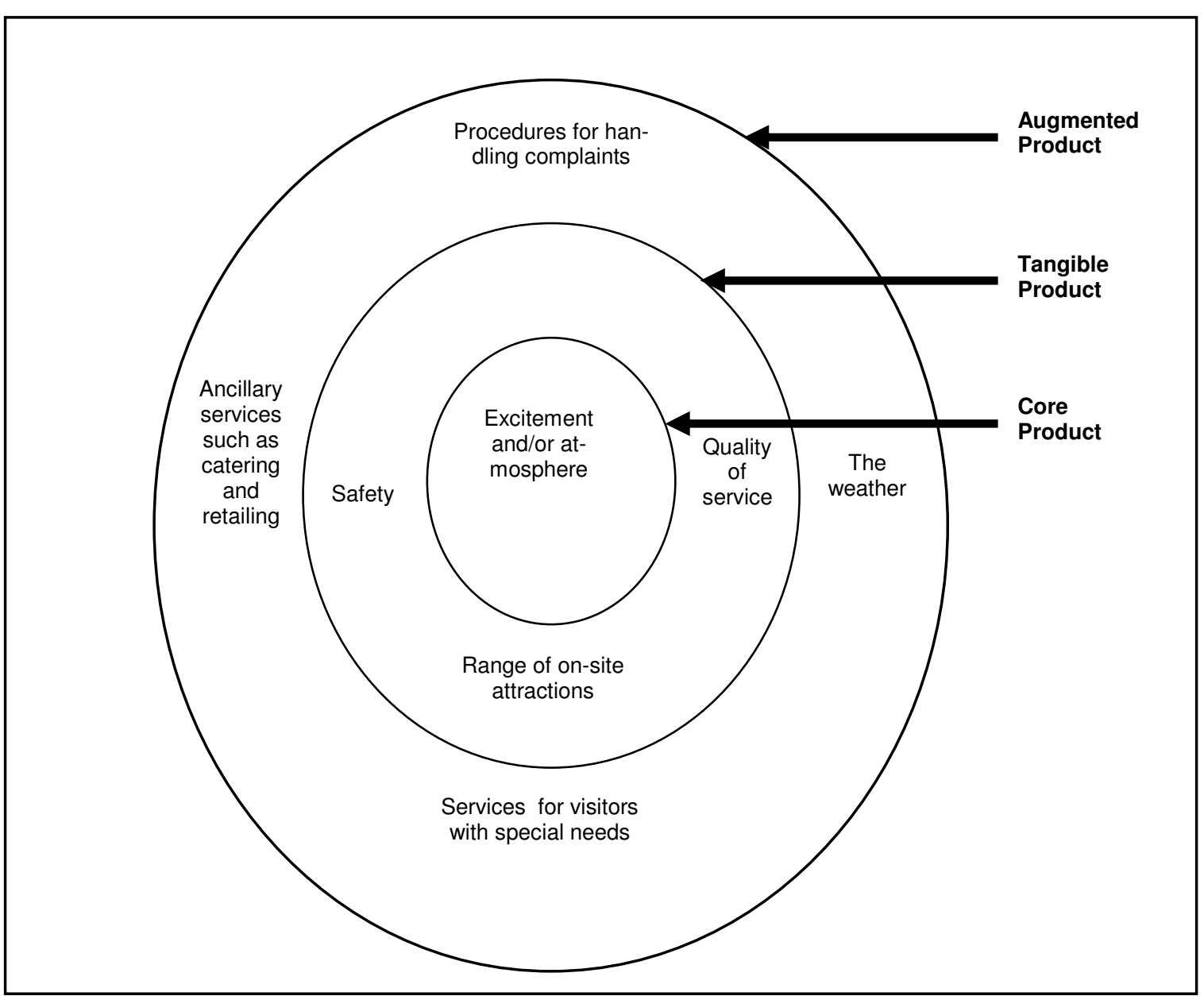

Figure 1:

The Three Levels of Product (Swarbrooke, 1995:46)

can be used in the PAR approach. It includes surveys, participant observation, qualitative in-depth interviews, focus groups, storytelling and drama (cultural theatre) (Strydom 2005(b):419). The techniques selected for this study were participant observation, focus group discussions characterised by in-depth interviews, and storytelling.

The strong emphasis on community involvement implied that a deliberate attempt was made to involve the residents of the visited homesteads, not only in data collection on their winter diet, but also in determining their opinions about tourists, the provision of food to the visitor motse, as well as the possible contribution of the visitor motse towards satisfying particular needs the local population have. The PAR approach enabled the researchers to explore the unique local knowledge and insights of the Hananwa on these aspects within the context of their own particular cultural and natural environment (cf. Babbie \& Mouton 2001:320; Collins 1999:102).

It has been mentioned above that the interviews were conducted in the context of focus group discussions. In fact, the presence of a number of women in the visited homesteads (metse) encouraged the involvement of participants and provided opportunities to investigate the winter diet of the Hananwa in greater depth. The interviews were conducted as open conversations (unstructured in-depth interviews), as described by Greeff (2005:292) with the specific aim of gaining insight into the dietary patterns of the homesteads that were visited on top of the mountain, in particular as far as the variety and preparation thereof are concerned. Each participant got the opportunity to ask questions, to make comments and to respond to the comments by others. The fact that people were interviewed in group context undoubtedly contributed to the spontaneity with which the participants contributed to the discussions, as the people tended to be reluctant to reveal information when they were interviewed individually. In fact, the interviewees expressed their preference to be interviewed in group context.

This technique of obtaining and generating data by means of group discussions in accordance with the PAR method is reported not only to be effective among people in rural and semi-urbanised areas where a high premium is generally placed on group participation (cf. Trollip 1991:77; Viljoen et al, 2005), but also among adults with low literacy skills (Keim et al. 1999). Hence, the size of the groups (small groups of people with a similar background and common in- 
terests) and characteristics of the actual interviews (the spontaneous focussed discussion of the topic by the participants) among the Hananwa homesteads (metse) visited, can best be described as focus group discussions, as delineated by Agar and MacDonald (1995), Greeff (2005:298-300), Schurink et al (1998:313-320).

While the actual interviews were being conducted, other members of the household went about their normal tasks and allowed the interviewer to observe them in their day-to-day tasks, e.g. fetching water and collecting firewood, herding animals, collecting grass for brooms and preparing various dishes. When it came to the variety of dishes that are prepared, the researchers soon realised that they had to be observant with regard to what food was in the storage hut and the cooking hut/kitchen at each motse, and that they should not rely solely on the inhabitants' indications of the composition of their diet. Thus the researchers made sure that they noted all the food types cultivated by the individual metse they visited as far as possible. In this respect Strydom (2005(a):277) remarks that '(t) o be able to listen, to see, to inquire, to observe and to write up the notes is of special significance in participation'.

Data was also recorded by means of photographs taken with the permission of the interviewees, as also recommended by Schurink (1998:284). The variety of food, the preparation thereof, as well as other activities (such as the manufacture of art and crafts) that could be significant for the study were photographed. A selection of these photographs is included in this article, not only as a record of the collected data, but also to demonstrate the value of these foodstuffs and their preparation as a tourist attraction.

In the last instance, the interviews did not only focus on the dietary habits of the Hananwa, but they also investigated the interviewees' attitudes towards tourism and tourists in the area in general, as this information would provide an indication of the viability and feasibility of the local Hananwa's providing the visitor motse with food. In order to obtain as full a picture as possible in this regard, semi-structured interviews were conducted with inhabitants in each of the homesteads (metse) that the researchers visited. Care was taken to include young and older people in the interviews. The semi-structured interviews consisted of pre -determined questions contained in an interview schedule. During the interviews this schedule was used as a guideline rather than as a rigid set of questions that all had to be asked and answered. The approach was rather one whereby the participants were given a topic and each was 'allowed maximum opportunity to tell his story', as suggested by Greeff (2005:296). Where necessary, follow-up questions were then asked to clarify the issues as much as possible.

\section{Language barrier}

The majority of people living on top of Blouberg do not understand English or Afrikaans at all, and they mainly speak Sehananwa, a North Sotho dialect (Van Wyk 1966:37). To overcome this difficulty, the services of an interpreter were acquired. Since one of the researchers speaks Sepedi, a Central Sotho dialect (Van Wyk 1966:37), the researchers are satisfied that they could verify the data in the sense that the true meaning of words and sentences were not obscured. However, questions about tourism tended to pose problems, as there are sometimes no North Sotho equivalents for English terms such as 'tourism' and 'tourist'. The meaning of such terms first had to be explained to the people before any meaningful interviews could take place. Questions concerning food issues posed no problems, as indigenous terms exist for all the foodstuffs cultivated by the Hananwa.

\section{Comprehension of questions}

Despite the fact that an interpreter was used and that the authors could understand the questions and answers in Sehananwa quite well, and that they are therefore satisfied that the respondents understood the questions, it was often difficult to get all the relevant information from them. The Hananwa tend to be rather reserved when dealing with strangers. The following is a typical scenario:

Interviewer: "What kind of meat do you eat?" Interviewee: "Chicken."

Interviewer: "Chicken only?"

Interviewee: "Yes, chicken only."

Interviewer: "Do you never eat any other kind of meat?"

Interviewee: "No, never."

Interviewer (noticing the goats): "Don't you ever eat goat meat?"

Interviewee: "Yes, we do."

Interviewer: "How often do you eat goat meat?"

Interviewee: "On special occasions like Christmas and Good Friday."

Interviewer: "Is there any other kind of meat that you eat?"

Interviewee: "No, only goat and chicken."

Interviewer (noticing the cattle): "Don't you ever eat beef?"

Interviewee: "Yes, we do."

Interviewer: "How often do you eat beef?"

Interviewee: "Once a month."

Similar scenarios arose with beverages - when they were asked what they drink, respondents would start out identifying only water, but eventually indicated that they also drank coffee, tea, traditional tea, traditional beer, commercially bought beer, etc. It is possible that some items could have gone unnoticed. However, those mentioned are definitely part of the local staple diet.

\section{COMMUNITY-BASED TOURISM DEVELOPMENT}

The establishment of a visitor motse on top of Blouberg (one which belongs to the community in the sense that they are solely responsible for its entire management and can also benefit from it financially by delivering services such as the provision of indigenous 
food, cooking and cleaning) is based on the principles of community-based tourism development. It entails the empowerment of the local community to ensure that the community members participate in their own planning and management and that they also exercise greater control over decision-making and the effects that tourism development may have on their culture and environment (Grobler 2005:1; Telfer 2002:47). In the words of Timothy (2002:150), community-based tourism development 'is about grassroots empowerment as it seeks to develop the industry in harmony with the needs and aspirations of host communities in a way that is acceptable to them, sustains their economies, rather than the economies of others, and is not detrimental to their culture, traditions or...day-to-day convenience'. Drumm (1998:212) expresses a similar view.

Two important aspects emerged in the process: participation by the community in decision-making and resident involvement in the benefits of tourism. Participation in decision-making entails that community members determine their own development goals and that they have a meaningful voice in the organisation and management of tourism in their area (Timothy 2002:152-153). According to Gunn (1994:111), such an approach improves the attitudes of destination communities towards tourism, resulting in a more successful industry, as tourism is largely dependent on the goodwill and cooperation of host communities. Furthermore, local attitudes towards tourism are significantly enhanced when residents are involved in the ownership and operation of facilities.

In this respect, the visitor motse provides ample opportunity to residents to become involved in smallscale, family-driven services to the motse. In addition, the cultural motse was designed to accommodate only ten people, not only to keep the impact on the local people and their environment as low as possible, but also to create conditions which will make it possible for tourists to have an authentic cultural experience. This approach is supported by Dahles (1997:23,24), who says: 'New forms of tourism are required that consist of smaller-scale, dispersed, and low-density tourism developments located in and organised by communities where it is hoped that they will foster more meaningful interaction between tourists and local residents... Small-scale tourism developments are much less likely to produce negative socio-cultural effects associated with foreign ownership. Local tolerance to tourism activities is significantly enhanced if opportunities exist for active resident involvement in the ownership and operation of facilities' (cf. Murphy 1985:153).

Resident involvement in the benefits of tourism implies that residents will gain personally from tourism. It is in particular by means of small-scale, locally-owned businesses that local people can benefit. Locallyowned enterprises have the further advantage that they can increase multiplier effects in the host community, cut down on foreign exchange leakages and reduce absenteeism of local residents from their homesteads in search of job opportunities (Dahles 1997:2324; Telfer 2002:59).
The opportunity for community members to provide food and associated services to the visitor motse on Blouberg could play a significant part in achieving the principles and objectives set by a community-based tourism development approach.

\section{COMMUNITY PERCEPTIONS OF TOURISTS AND TOURISM}

Development projects that are initiated by members of a community usually have the best chance of being a success. When development projects are initiated from outside, the risk of failure is higher. This is especially true in rural areas where communities have apparently come to accept poverty as a given, and as a result judge all attempts from outside to change their circumstances and improve productivity as unrealistic. Creativity, voluntary activities and accepting responsibility and leadership are not typical of such communities (Wassermann \& Kriel 1997:69-70). As the potential of improving the living conditions of the people on top of the mountain by giving them an opportunity to share in the provision of food to the visitor motse was not identified by the community but was identified from outside, it was deemed necessary to determine the community's perception of and attitude toward tourists and tourism.

Berno (1999) states that 'it is clear that when the term "tourist" is used cross-culturally, it is important to define from an emic stance the native people's understanding of both their own form of travel, and of Western tourism'. The Hananwa language has no equivalent term for the word 'tourism' or 'tourist'. The Hananwa's understanding of tourism is to visit a place other than home, and they were unanimous that a tourist is a 'visitor' or 'guest'. People 'visit' for various reasons, including seeing family or friends, going to a festival, attending a funeral, etc. This implies that the community-based tourism (CBT) concept was also completely new to them. Once the concept had been explained to them, they supported the idea of community ownership, as it signifies a means of improving their living conditions with outside assistance.

The interviewees were divided on the issue of whether cultural tourism would strengthen their cultural heritage, as opposed to the view that cultural tourism would cause their traditions to change. One old woman was very distrustful and did not want any tourism. 'It is meant to change our lives,' she declared. There was, moreover, a clear division between the opinions of young adults and adults who are pensioners. The older people were initially slightly more distrustful, but once it had been explained that they would not be required to change their ways in any way, they were more positive. They found it strange that people from the outside would be interested in their culture and in particular their food and eating habits. They asked: 'Why would people from outside be interested in visiting poor people?' On the one hand, they feared change and the unknown and, on the other hand, they had an overwhelming desire to improve their living conditions. They also feared that 
tourists would take their land or make them abandon their culture. Although it could not be confirmed, this fear could possibly be ascribed to the 1894 HananwaBoer war when they were indeed removed from Blouberg and had to work for farmers under conditions totally different from their own cultural practices. The young adults, however, did not share this initial fear or the scepticism of the older generation and they were all very positive about the idea. They felt that tourism could provide the necessary financial injection the community needs. However, everyone agreed on one point and that is that tourism would be good in that it would provide job opportunities. A young man revealed considerable insight in the whole concept of community-based tourism when he said: 'Tourism will be very good because then we can teach other people (tourists) about our culture and at the same time learn about other people's culture. Young people of my age miss the opportunities presented by tourism. If people (tourists) would visit us (the people on the mountain), it will provide people like me with the opportunity to stay and work on the mountain.'

Marijuana (cannabis sativa) is found in abundance on Blouberg mountain. In the course of the study it came to light that the selling of marijuana was an important source of income for many homesteads. As it could affect the willingness and enthusiasm of the people to provide the visitor motse with food, it was deemed necessary to weigh the importance of marijuana against the provision of food to the visitor motse as a source of income. There was a difference of opinion: some would supply the visitor motse with food as an additional source of income to selling marijuana, while others would rather replace marijuana by supplying the visitor motse with food as a source of income because of the risk of being prosecuted by the police for selling marijuana, which is illegal in South Africa.

Eventually all the respondents on top of the mountain, including those who regarded the provision of food to the cultural motse as an additional source of income to marijuana as well as members of the older generation, with one exception, expressed a very positive attitude towards tourism and said that they would welcome tourists in their area. However, there was a precondition: the majority of the people the researchers visited considered it to be important that visitors be accompanied by a local guide and that they respect Hananwa etiquette and culture. These findings correspond to a large extent with those of Grobler (2005:36 -53) among the Venda in the Tshivhase area in the Soutpansberg.

The survey on the Hananwa's perceptions of and attitudes towards tourists and tourism gave a clear indication of the feasibility of tourism on top of Blouberg. It must be emphasised that respecting the cultural values and norms of the Hananwa and a restriction of tourist numbers must be regarded as a prerequisite for sustainable tourism on top of the mountain.

\section{CONSERVATION OF CULTURAL HERITAGE}

The impressive mountain with its rich and abundant vegetation is itself an exceptional attraction. The majority of interviewees were of the opinion that the main reason why people would want to visit this region would be to see the mountain. Because they rely so heavily on their natural environment for their survival, the Hananwa are acutely aware of conservation issues and they insist that their principles in this regard be respected by visitors. The visitor motse is small and can accommodate only ten people at a time, which means that even if the visitor motse is occupied throughout the year, the tourists should not have any significant effect on the natural environment.

The community is, moreover, the custodian of an equally sought-after tourist attraction, namely a unique traditional culture - a unique way of life. The word 'tradition' can be defined as an 'opinion or belief or custom handed down from one generation to another' (Swannell 1987:597). Seen in this light, today's newly acquired beliefs and customs can become the traditions of future generations. The isolated nature of this community does not mean the people have not been exposed to western customs. They have chosen to live their old traditional way and they conserve their traditions very strongly. To what extent continuous contact with other cultures will alter their way of living and decrease its value as a tourist attraction, only time will tell.

Given that culture is humans' main way to adapt to their environment and circumstances, culture is by its very nature dynamic and ever-changing. Tourism in itself should not be blamed for affecting a culture's authenticity. If a community lives in a particular way which is generally accepted by its members, that way has to be regarded as real and thus authentic. It cannot be considered authentic when a community is portrayed as living in a kind of time capsule which has somehow managed to escape the effects of the modern world (Cohen1995:13)

The Hananwa should rather present themselves as a community that has survived precisely because they have managed to make the best of both worlds. On the one hand, they produce food using the ways their ancestors have used for generations before them, because it is the least expensive way to do so, but on the other hand, they are not opposed to buying items that would be more costly to produce themselves (such as soap and oil) or to procure an income by means of cultural tourism. With regard to the latter means of income they should not be denied this opportunity to create their own wealth and comfort simply because by doing so they may lose some of their so-called 'authenticity'. With careful capacity-building, the Hananwa community should be able to conserve and protect the Hananwa culture against the kinds of commoditisation and commercialisation that are often the result of tourism.

The researchers are well aware of the traditional subordinate position of women among most African communities (Schapera 1959:188). However, according to our informants the selling of marijuana by Hananwa 
women has led to some level of emancipation of the women, because the women keep part of the income on condition that it will be used to support their families. Originally, all income generated by a woman had to be given to her husband. The income obtained from the provision of food to the visitor motse should not cause any tension between husband and wife, provided that part of the income is given to the husband. In this respect it has to be noted that some women are members of the Community Tourism Association mentioned above. It is expected that it will contribute to their emancipation, as their function is to assist with the identification and development of cultural activities that might be attractive to tourists. The provision and preparation of traditional food for the visitor motse provides an excellent opportunity in this respect.

With regard to both the natural and cultural heritage, Sofield and Birtles (1996:397) explain that the primary objectives of cultural tourism to many indigenous communities are to restore, protect and conserve their cultural heritage, which of necessity includes this biophysical environment. Particular elements of their heritage are presented to visitors and others. At the same time their cultural heritage is transmitted to successive generations of their own people. This also applies among the Hananwa, as the same objectives are pursued at Blouberg.

\section{DIETARY HABITS OF THE HANANWA}

Because Blouberg is situated in a summer rainfall area and crop production is less extensive in winter, it was decided to assess the winter diet and availability of food during that time to gauge the community's ability to provide the motse with food throughout the winter months as well as the role that food provision can play in tourism to this area. It was assumed that if the community could supply food during winter, there would be no problem in supplying food in summer, when supplies are more plentiful.

In contrast to the western custom of eating three meals a day, according to Hananwa custom, people only eat two meals a day: one in the late morning and one in the early evening. Food is mostly cooked on an open fire outside, but on rainy days the cooking hut is used. Traditional beer, however, is always made inside.

[Maize (lefela) (zea mays), marôgô/theepe (amaranthus thumbergii), a variety of pumpkin types (int. al. cucurbita pepo and lagenaria siceraria - the bottle calabash, known in the vernacular as legapa), watermelons (morôtsê) (citrillus vulgaris) and beans (dinawa) (vigna subterranea) form the staple diet of the Hananwa during the dry winter season, as is the case among the majority of other indigenous groups living in rural areas with a similar climate. All of these foods are grown and harvested during the rainy season; and maize, marôgô, grain sorghum (sorghum bicolor) and beans are stored for the winter months.

The community members cultivate beans (dinawa), especially jugo beans (vigna subterranean). The

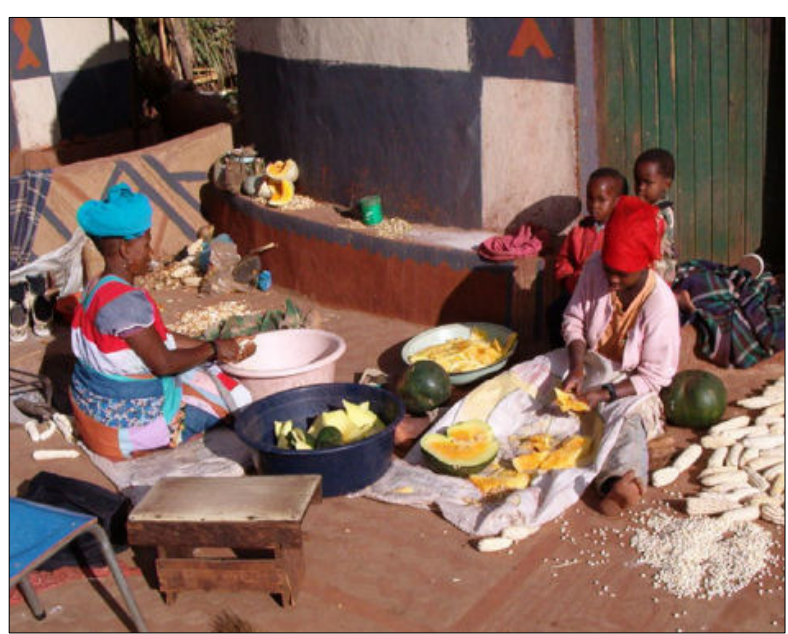

Photo 1: Mother and daughter preparing mealies (lefela) and watermelon (morotse) for the evening meal

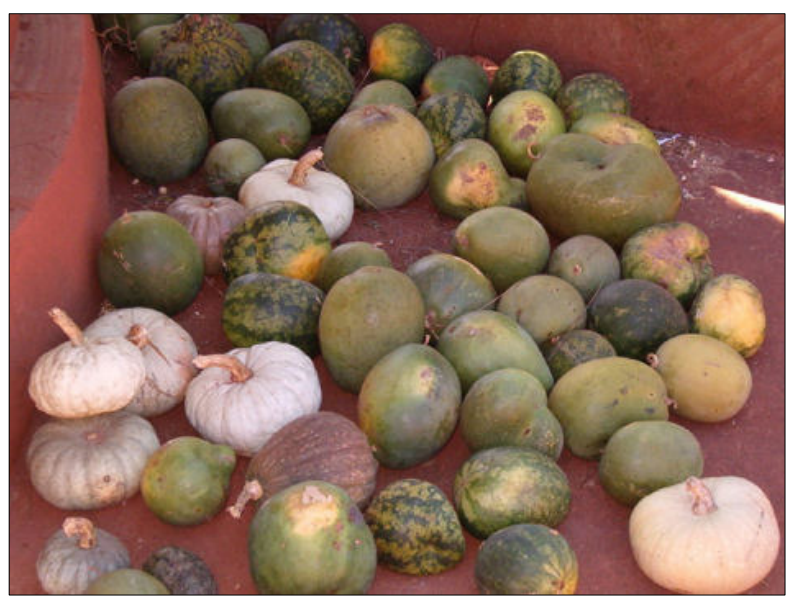

Photo 2: Pumpkins (mopotse) and watermelons (morôtsê)

beans are often intercropped with maize and pumpkin. Van Wyk and Gericke (2000:28) describe it as an annual herb of which several cultivars are found in southern Africa, 'differing mainly in the colour of the seed: black, spotted, yellow-brown, red or cream'. There are various traditional recipes for preparing dishes from the cooked, crushed beans. A dish called mmoto is prepared by cooking the beans in salted water, draining the water and mashing the beans mixed with some cooking oil. Another bean dish consists of beans mixed with samp (lewa) (cf. Van Wyk \& Gericke 2000:28).

[Maize forms the most important part of the daily diet and is eaten twice a day - on its own for breakfast and served with a side dish like marôgô or pumpkin (mopotse) (and sometimes meat) for the main meal. Sorghum can be used as a porridge (also known in South Africa as malted mabêlê or maltebêlê) but, among the Hananwa, it is more often used for making traditional beer (cf. Van Wyk \& Gericke 2000:14).

[Watermelon (morotse) is eaten raw, dried or cooked. 


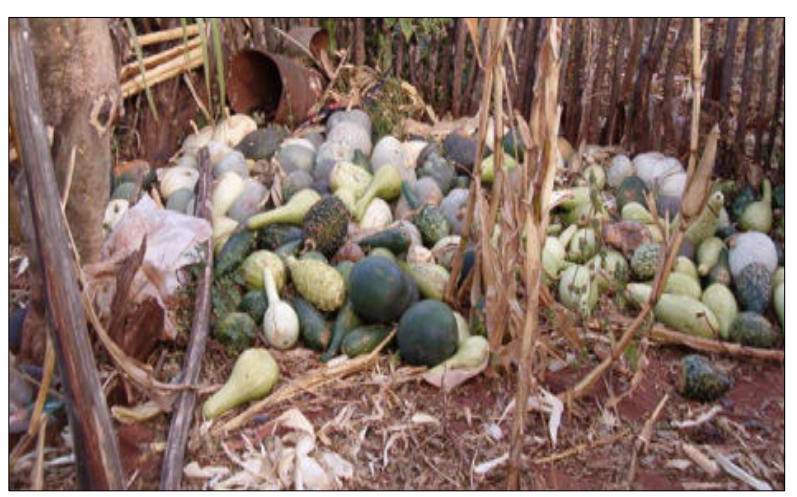

Photo 3: Bottle calabash (legapa) and watermelons (morôtsê)

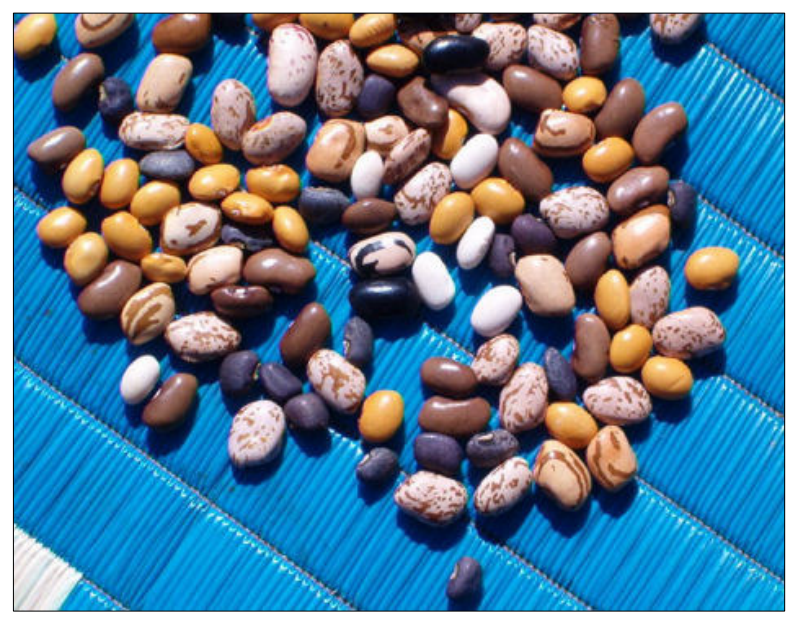

Photo 4: Beans (dinawa)

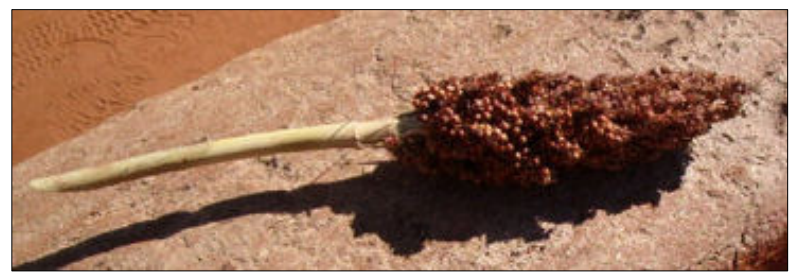

Photo 5: Sorghum (mabêlê)

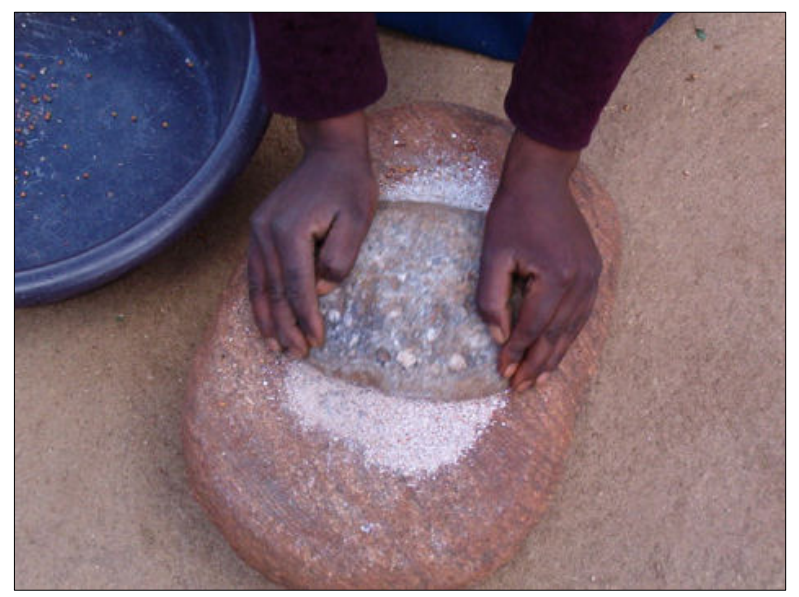

Photo 6: Grinding of maize (lefela)
In its raw form it is called mogodu and if it is cooked, it is called lerotse. Watermelon is also very often used in a dish called thopi. The watermelon is sliced, seeded and boiled for approximately 20 minutes in salted water. Afterwards the water is drained and the watermelon is mashed. The mashed mixture is then mixed with cooked maize meal. The result is very similar to mealie (corn) bread, with a slightly sweet taste, and it goes very well with meat.

Pumpkin is usually eaten as a dish on its own - boiled in water with salt and a dash of sugar. Both watermelon and pumpkin pips are dried (only wind dried) and then fried in a hot pan with salt (no oil is used). This makes a very tasty snack.

Other than gathering dead wood for cooking fires and the leaves of certain plants for traditional tea, a minimal amount of natural resources are used in the winter months. Traditional tea is dried in small bundles with the leaves still attached to the stems. A whole bunch is put in a kettle with boiling water and left to steep. The tea has a very refreshing taste, not unlike many other commercially available kinds of herbal or green tea.

A plant of particular importance is marôgô as it forms a major part of the winter staple diet of the Hananwa. Among the Hananwa, it is more specifically indicated as theepe (amaranthus thunbergii). A nutritional analysis of this plant has revealed that the nutrient content (protein - 3,5 g/100g; iron - $8,5 \mathrm{mg} / 100 \mathrm{~g}$; calcium - $272.2 \mathrm{mg} / 100 \mathrm{~g}$; beta-carotene 2343,66 $\mu / 100 \mathrm{~g}$ ) (Steenkamp 2005:25; Steenkamp \& Schönfeldt 2005) is of particular significance in a marginalised area where the consumption of animal products is also low. The leaves are laid out to dry after harvesting, cooked like spinach and has a very similar taste. It is mostly eaten as a side dish to the main meal, which is eaten in the early evening.

Note that these nutritional values for marôgô differ from the high values provided by Quin (1959:61) and Van Wyk and Gericke (2000:64) - the reason being that their valuations were reported on a dried matter basis while Steenkamp (ibid) and Steenkamp and Schönfeldt's (ibid) valuations reflect the nutrient content of the cooked leaves of marôgô, as consumed.

Other forms of protein include chicken, beef, goat meat and even mutton. Of these, chicken is eaten most often. The meat is boiled at a high temperature until all the water has evaporated and only the oily juices are left. Then the meat is fried in the juices at the same high temperature until the meat has browned. Chicken feet, the head and intestines are favourites and they are available from the local shops at very affordable prices. The intestines are washed, cleaned out and then fried in oil. They not only look very similar to calamari but also taste surprisingly similar. Note that it is taboo for women to eat the 'pope's nose' (kgôthô ya kgogo), as it is strictly reserved for the head of the motse. It is believed that if a pregnant woman dares to eat this part of a chicken, that would lead to spontaneous abortion. It is also taboo for a pregnant woman to eat eggs, as it is be- 


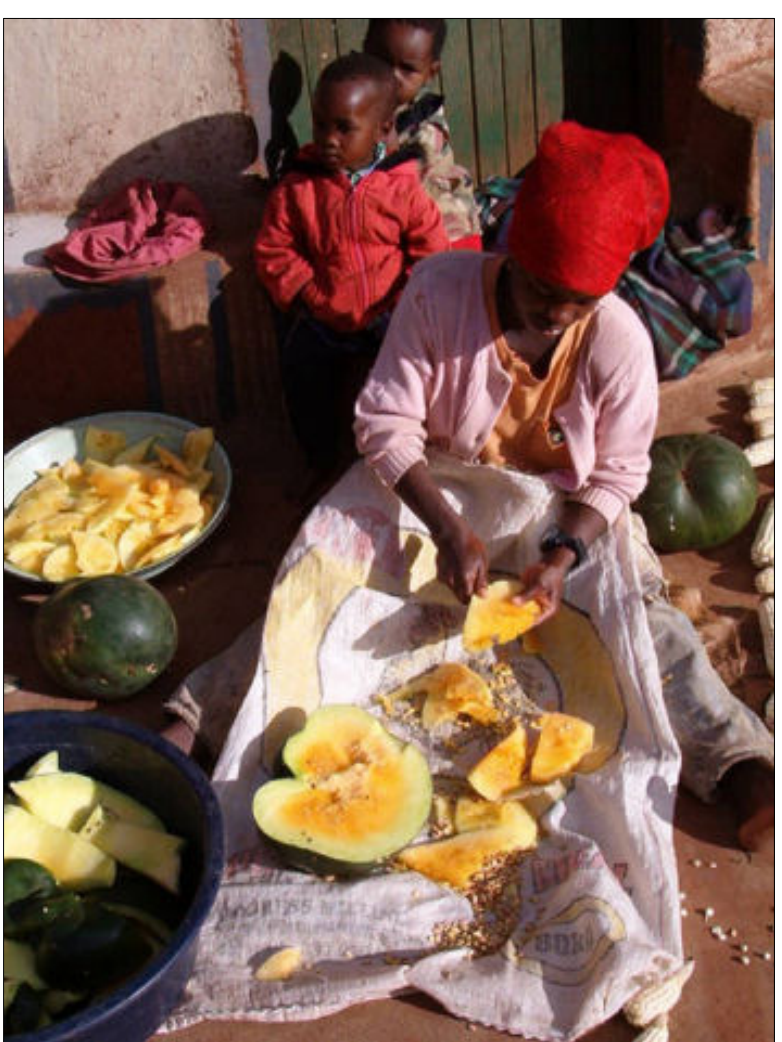

Photo 7: Watermelon (morotse) and pumpkin (mopotse)

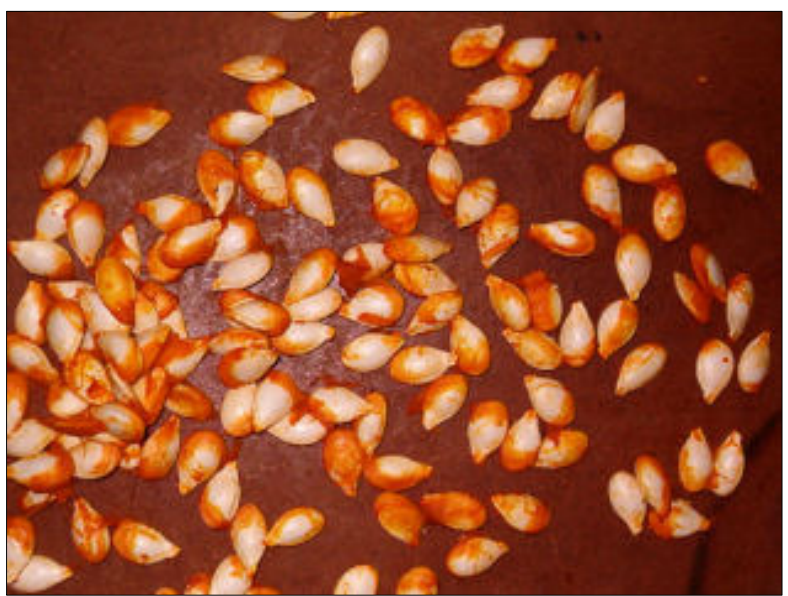

Photo 8: Pumpkin pips

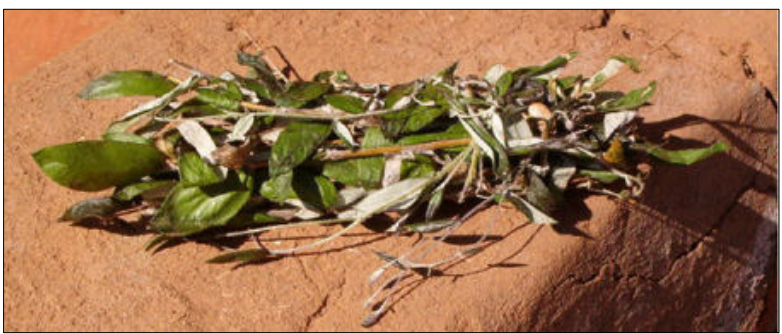

Photo 9: Traditional tea (mohlwahlwaila) lieved that the fetus will grow so huge that she will not be able to give birth, causing her death and that of the child. Schapera (1959:133) remarks that it is taboo for a woman to eat eggs, because it is believed that it will make her lascivious. This belief could not be confirmed among the Hananwa, possibly because one of the researchers is a man, and women in rural societies will not answer questions of this nature in the presence of a man. According to Coetzee (1982:168), no chicken or other domesticated birds were raised in traditional society. However, wild birds were often hunted for the pot. Wild birds were cooked by trussing them, stewing them slowly till soft, and the meat was served with gravy.

One of the most basic ways this community can benefit from tourism is by providing the raw food supplies, as well as a catering service whereby tourists can be introduced to the local cuisine. This can be combined with introducing the tourists to the local customs and beliefs concerning food and the preparation and consumption thereof.

Tourists used to a more varied western diet might find the local Hananwa winter diet very monotonous. Certain traditional dishes, however, could be very successfully combined with western food to provide the best culinary experiences of both worlds to tourists. The researchers acknowledge that some of these recipes have been inspired by the traditional recipes described by Coetzee (1982:119-177).

1. Mabêlê (sorghum porridge) could be served with bacon and eggs and toast for a hearty breakfast before the visitors embark on a lengthy cultural route hike. Sorghum porridge is a traditional favourite and 'has an attractive reddish-brown colour and an appetising, nutty-sweet taste... On contemporary breakfast tables the malted sorghum porridges are not only attractive, but pleasant tasting as well' (Coetzee 1982:136).

2. Malana (head, feet and intestines of chicken) probably best served without the head and feet could be served on a bed of rice as a light lunch with a side serving of fresh green salad. (A suggestion would be to call this dish "Bushveld calamari".)

3. Mmoto (mashed beans - similar in taste to Mexican refried beans) could be served with chicken cooked in the traditional way with a serving of marôgô/theepe for some colour and added nutrition for a fully traditional dinner. In terms of western tastes, this dish could be an attractive variation to the traditional diet according to which bean relishes were served as a side dish with porridge (cf. Coetzee 1982:161).

4. Traditional tea could become a favourite amongst the health conscious and could be served for midmorning tea and/or in the late afternoon.

5. Thopi (a mixture of watermelon and maize meal) makes a wonderful accompaniment to barbecued meat or chicken. One could perhaps add a side serving of marôgô/theepe and pumpkin.

6. Pan-fried watermelon and pumpkin pips could be served with sun dried strips of watermelon 


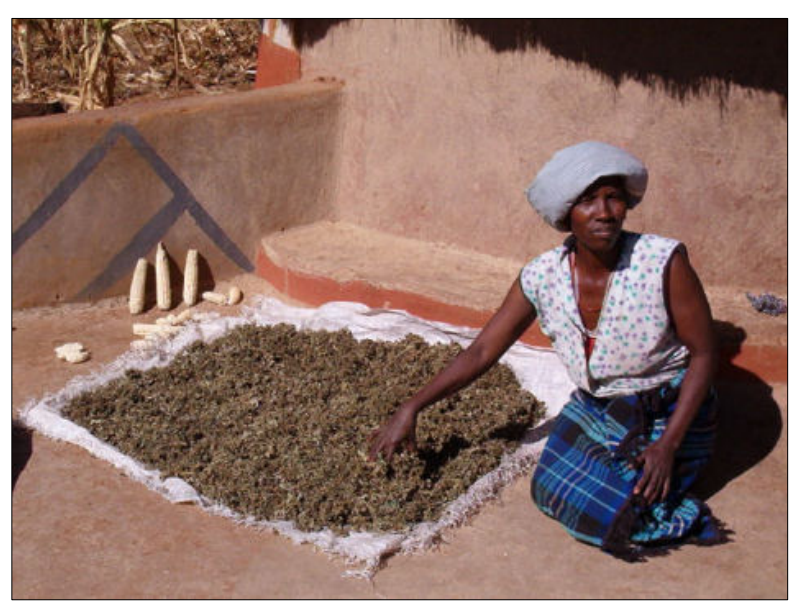

Photo 10: Marôgô/theepe: laid out to dry after harvesting

(another local use for watermelon) as a snack with sundowners. This dish also offers an attractive alternative to the traditional one described by Coetzee (1982:156) which consists of roasted pumpkin pips served as a tasty accompaniment to sorghum porridge.

7 Traditional beer is an acquired taste to most westerners, but tourists should at least be afforded the opportunity to taste it and should most definitely be shown how it is made. Sorghum beer is prepared in great quantities by the Hananwa at the top and the bottom of the mountain. Marula beer, which is usually acceptable to most (including western) tastes is, however, only produced at the bottom of the mountain, as there are no marula (sclerocarya caffra) trees on top of the mountain. Over a period of a few years during which the mountain was also visited during marula time - that is in February no marula beer was ever found on top of the mountain.

Apart from the traditional dishes, a variety of dishes could be prepared from ingredients supplied by the local people. All these food products mentioned and produced by the local people should be used in preference to any shop-bought items that would in any case create additional costs, as porters have to get the food to the top of the mountain.

Smith (1989:287-289) refers to the 'four H's' of indigenous tourism, namely being habitat (the geographic setting), heritage (ethnographic traditions), history (the effects of acculturation) and marketable handicrafts. Food can be used as an underlying theme in all four these categories. What local foods are grown or harvested in the area? How is the natural habitat used to supplement the diet? (habitat). Why are certain foods preferred above others? What are the gender roles in food-related issues such as planting, harvesting, collecting, preparing and serving food? What role does food play in specific cultural festivals? (heritage). Which western dietary habits have been adopted and incorporated as part of the traditional diet? (history acculturation). Which handicrafts have their origin in food production but have subsequently become popular among tourists? (handicrafts).

\section{CONCLUSION}

The Blouberg visitor motse provides feasible opportunities for the local Hananwa to participate as managers, operators and owners of resources and providers of products sought-after in the tourism industry to benefit the community through the establishment of community-based projects. The variety of foods identified and observed in the homesteads that the researchers visited indicates that it would be possible to provide the visitor motse with food to the satisfaction of tourists. Simultaneously, the food variety makes it possible for homesteads to become involved in their own tourism development on a family-owned, smallbusiness scale basis. This is, of course, in accordance with the principles of community-based tourism development, as it will enable community members to take ownership of their own enterprises, which results in benefits to the local economy (cf. Dahles 1997:23).

The fact that the visitor motse has been designed to accommodate only ten people is a clear indication of the intention (at least from the Provincial Government's side), to promote responsible tourism on top of the mountain. This will undoubtedly contribute towards restricting the impact of tourism on the natural, cultural, archaeological and historical assets on the mountain. The limited accommodation capacity of the visitor motse could play a major role in ensuring the continued positive attitude of residents towards tourists and tourism in the area.

The research has clearly shown that the cultivation, provision and preparation of food for the visitor motse will be the responsibility of the women on the mountain. This finding brings a new dimension to tourism development on Blouberg, as the involvement of women in the visitor motse could open the door for women to get a greater share in decision-making and planning in tourism development. Furthermore, it will enhance the objectives and principles of communitybased tourism insofar as it implies the involvement of all community members, irrespective of gender. In this respect, Timothy $(2002: 155)$ says that '(t)he political rights of women and ethnically diverse residents and their entitlement to participate in tourism planning and decision-making are ill-defined in tourism policy and practice... Women and racial minorities must be given a louder voice in policy-making if the goals of sustainability are to be realised, for these people are an important part of the community who are affected directly and indirectly by tourism' (Timothy 2002:155).

These objectives can, however, only be achieved by using continuous training programmes to empower the community on top of the mountain to become entrepreneurs and participants in and beneficiaries of the tourism industry. It involves education, as well as awareness-building. Community-based tourism initiatives require that residents be informed and knowledgeable about the industry and its potential. In the 
developing world (which includes Blouberg) residents have little first-hand knowledge or experience of tourism and about being tourists. In fact, these are strange concepts to them, as this research and that of Grobler (2005) has shown (cf. Timothy 2002:158). Not only public awareness but also natural and cultural awareness are necessary to make community-based tourism feasible, viable and sustainable.

In conclusion, the Hananwa of Blouberg have the ideal combination of factors to turn their cultural heritage into a form of sustainable income, whilst at the same time preserving their heritage in a way they can control themselves. What remains to be explained is that job opportunities can take various forms and do not necessarily involve providing services like cleaning, cooking, ironing, etc. but could also involve the provision of more tangible goods like food, crafts and, most important, exposure to their culture. By emphasizing the provision of food to the visitor motse as the underlying theme, the pivotal role of women in an otherwise paternalistic society can also be illuminated and enhanced.

\section{REFERENCE LIST}

AGAR M \& MACDONALD J 1995 Focus groups and ethnography. Human Organization 54(1):78-86.

BABBIE E \& MOUTON J 2001 The practice of social research. South African edition. Cape Town. Oxford University Press.

BERNO T 1999 Cross-cultural research methods: content or context? A Cook Islands example. Annals of Tourism Research 26(3):656-675.

BREUTZ P L 1953 The tribes of Marico district. Department of Native Affairs. Ethnological Publications no. 30. Pretoria. Government Printer.

COETZEE J K, GRAAFF J, HENDRICKS F \& WOOD G 2001 Development theory, policy, and practice. Oxford. Oxford University Press.

COETZEE R 1982 Funa food from Africa: Roots of traditional African food culture. Durban. Butterworths.

COHEN E 1995 Contemporary tourism - trends and challenges. Sustainable authenticity or contrived postmodernity? In BUTLER R \& PEARCE D (eds.) Change in tourism, people, places, processes. London. Routledge.

COLLINS K 1999 Participatory research. A primer. Johannesburg. Prentice Hall.

DAHLES H 1997 Tourism, small entrepreneurs, and sustainable development. Tilburg University, The Netherlands. ATLAS.

DIRECTORATE TOURISM 2002 African Ivory Route Ecotourism Operational Project. Polokwane, Limpopo Province. The Department of Finance, Economic Affairs and Tourism and the SMME.

DRUMM A 1998 New approaches to communitybased ecotourism management: Learning from Ecuador. In LINDBERG K, WOOD M \& ENGELDRUM D (Eds.) Ecotourism, A guide for planners and managers. Vol. 2 (pp. 197-213) North Bennington, VT. The International Ecotourism Society.

GREEFF M 2005 Participatory action research. In DE VOS A S, STRYDOM H, FOUCHÉ C B \& DELPORT
C S L (eds) Research at grass roots. Pretoria. Van Schaik.

GROBLER J H F 2005 Community perceptions of tourism in the Tshivhase area, Limpopo Province. MHCS-mini dissertation, University of Pretoria, Pretoria.

GUNN C 1994 Tourism planning. $3^{\text {rd }}$ ed. New York. Taylor and Francis.

JOUBERT A \& VAN SCHALKWYK J A 1999 War and remembrance: the power of oral poetry and the politics of Hananwa identity. Journal of Southern African Studies 25(1):27-45.

KEIM K S, SWANSON M A, CANN S E \& SALINAS A 1999 Focus group methodology: adapting the process for low-income adults and children of Hispanic and Caucasian ethnicity. Family and Consumer Sciences Research Journal 27(4):451-465.

KRIGE J D 1937 Traditional origins and tribal relationships of the Sotho of the Northern Transvaal. Bantu Studies 11(4):321-356.

LESTRADE G P 1928 Some notes on the political organization of the Bechwana. South African Journal of Science 25:427-432.

MURPHY P 1985 Tourism: a community approach. New York. Methuen.

PELTO P J \& PELTO G H 1978 Anthropological research. $2^{\text {nd }}$ ed. Cambridge. Cambridge University Press.

QUIN P J 1959 Foods and feeding habits of the Pedi. Johannesburg. Witwatersrand University Press.

ROBERTS N 1916 The Bagananoa or Ma-Laboch: notes on their early history, customs and creed. South African Journal of Science 12:241-256.

SCHAPERA I 1959 The Bantu-speaking tribes of South Africa. Cape Town. Maskew Miller.

SCHURINK W J 1998 Participant observation. In DE VOS A S (ed) Research at grass roots. A primer for the caring professions. Pretoria. Van Schaik.

SCHURINK W J, SCHURINK E M \& POGGENPOEL M 1998 Focus group interviewing and audio-visual methodology in qualitative research. In DE VOS A S (ed) Research at grass roots. A primer for the caring professions. Pretoria. Van Schaik.

SMITH V L 1989 Indigenous tourism, the four H's. In Smith V L Hosts and Guests. Philadelphia. University of Pennsylvania Press.

SOFIELD T H B \& BIRTLES R A 1996 Indigenous peoples' cultural opportunity spectrum for tourism (IPCOST). In BUTLER R \& HINCH T (eds) Tourism and indigenous peoples. London. Thomson.

SONNTAG C n.d. My friend Maleboch, chief of the Blue Mountains. Pretoria. Sigma.

STEENKAMP E 2005 Nutrient content of five traditional green leafy vegetables of South Africa. BSc (Hons)-research essay. University of Pretoria.

STEENKAMP E \& SCHÖNFELDT H C 2005 Nutrient content of five traditional green leafy vegetables of South Africa.B15. $6^{\text {th }}$ International Food Data Conference. Food Composition and the Nutrition Dilemma, 14-16 September, Pretoria, South Africa. (Poster).

STRAUSS A \& CORBIN J 1998 Basics of qualitative research. $2^{\text {nd }}$ ed. London. Sage.

STRYDOM H 2005(a) Information collection: participant observation. In DE VOS A S, STRYDOM H, FOUCHÉ C B \& DELPORT C S L (eds) Research at 
grass roots. Pretoria. Van Schaik.

STRYDOM H 2005(b) Participatory action research. In DE VOS A S, STRYDOM H, FOUCHÉ C B \& DELPORT C S L (eds) Research at grass roots. Pretoria. Van Schaik.

SWANNELL J 1987 The little Oxford dictionary of current English. Oxford. Oxford University Press.

SWARBROOKE J 1995 The development and management of visitor attractions. Oxford. Butterworth and Heinemann.

TELFER D J 2002 Tourism and regional development issues. In SHARPLEY R \& TELFER D J (eds) Tourism and development: concepts and issues. Toronto. Channel View.

TIMOTHY D J 2002 Tourism and community development issues. In SHARPLEY $R$ \& TELFER $D \mathrm{~J}$ (eds) Tourism and development: concepts and issues. Toronto. Channel View.

TROLLIP A M 1991 Die betekenis van geakkultureerde kledingpraktyke vir geselekteerde Ndzundza-Ndebele-vroue. PhD-tesis. Universiteit van Pretoria.
VAN SCHALKWYK J A 1995 Ideologie en die konstruksie van 'n landelike samelewing: 'n antropologiese studie van die Hananwa van Blouberg. D.Phil-thesis, Universiteit van Suid-Afrika, Pretoria.

VAN SCHALKWYK J A \& MOIFATSWANE S M 1991 The siege of Leboho: South African Republic fortifications in the Blouberg, Northern Transvaal. Krygshistoriese Tydskrif 8(5):175-183.

VAN WYK B \& GERICKE N 2000 People's plants: a guide to useful plants of southern Africa. Pretoria. BRIZA.

VAN WYK E B 1966 Die Bantoetale. Pretoria. Van Schaik.

VILJOEN AT, BOTHA P \& BOONZAAIER C C 2005

Factors contributing to changes in food practices of a black South African community. Journal of Family Ecology and Consumer Sciences 33:46-62.

WANG N 1999 Rethinking authenticity in tourism experience. Annals of Tourism Research 26(2):349-370. WASSERMANN I \& KRIEL J D 1997 Facts and fallacies: Perspectives on development. Pretoria. The Authors. 